STUDIA I PRACE WYDZIAKU NAUK EKONOMICZNYCH I ZARZĄDZANIA NR 39, t. 1

DOI:10.18276/sip.2015.39/1-08

\title{
Anna Wieczorek-Szymańska*
}

Uniwersytet Szczeciński

\section{ORGANIZACJA FRAKTALNA W GOSPODARCE SIECIOWEJ}

\begin{abstract}
Streszczenie
$\mathrm{W}$ artykule zaprezentowano koncepcję organizacji fraktalnej jako nowoczesnej formy organizacji, która odpowiada wymaganiom gospodarki sieciowej. Przedstawiono różne ujęcia definicyjne fraktali, ich cechy charakterystyczne, a także potencjalne wady i zalety wdrażania struktury fraktalnej.
\end{abstract}

Słowa kluczowe: gospodarka sieciowa, organizacja fraktalna, zarządzanie

\section{Wprowadzenie}

Zarządzanie relacjami z klientem, kluczowe znaczenie kreatywności i wiedzy pracowników w tworzeniu wartości dodanej, orientacja procesowa, rosnąca rola internetu w procesach gospodarczych to tylko niektóre wyzwania, jakie niesie nowa gospodarka. Tradycyjnie - pionowo - zorganizowane przedsiębiorstwo, nastawione na standaryzację procesów, postrzegające otoczenie jako źródło zagrożeń, a innych uczestników rynku jako rywali, z którymi należy walczyć, nie jest zdolne do ela-

\footnotetext{
*Adres e-mail: wiean@wneiz.pl.
} 
stycznego i szybkiego reagowania na zmieniające się trendy gospodarcze. W związku z tym pojawia się konieczność zmiany podejścia do zarządzania przedsiębiorstwem.

Celem artykułu jest przedstawienie idei gospodarki sieciowej i koncepcji organizacji fraktalnej jako tej, która odpowiada wymaganiom tzw. nowej gospodar$\mathrm{ki}^{1}$ (The New Economy).

\section{Nowe warunki funkcjonowania organizacji - gospodarka sieciowa}

Filozofia „nowej gospodarki” opiera się na rosnącym znaczeniu informacji i sieciowych systemów cyfrowych. Dlatego też można ją określić mianem gospodarki sieciowej ${ }^{2}$. W takiej gospodarce procesy rynkowe przebiegają bardzo dynamicznie i burzliwie, tworzone są nowe zasady działania, gdzie w miejsce klasycznego konkurowania $\mathrm{z}$ innymi podmiotami pojawia się szeroko rozumiana kooperacja $\mathrm{w}$ formie różnie zorganizowanych sieci. Reguły rządzące funkcjonowaniem gospodarki sieciowej można sprowadzić do następujących ${ }^{3}$ :

1. Obfitości - sieci dają możliwość zwiększania wartości dodanej poprzez występowanie efektu synergetycznego.

2. Wykładniczego wzrostu wartości - rozwój systemów technologicznych spowodował, że w przedsiębiorstwach, w których w ciągu pierwszych 10-30 lat działalności występował minimalny wzrost zysków, dziś obserwuje się gwałtowne wzrosty, które można opisać funkcją wykładniczą.

3. Rosnących zwrotów - pojawienie się kolejnego podmiotu w sieci przyciąga więcej kapitału i kolejnych uczestników, którzy tworzą wartość sieci.

4. Lojalności - w ramach sieci trudno jest jednoznacznie wskazać centrum oraz wyraźne granice. Pojawia się więc problem z lojalnością uczestników sieci, ponieważ sieć nie jest bytem stałym, ulega permanentnym przeobrażeniom, a więc zmienny jest także jej skład.

1 Nowa gospodarka, określana także mianem gospodarki opartej na wiedzy (Knowledge-based Economy) czy gospodarki napędzanej wiedzą (Knowledge-driven-economy).

2 D. Tapscott, Gospodarka cyfrowa. Nadzieje i niepokoje Ery Świadomości Systemowej, Business Press, Warszawa 1996, s. 7-10, za: K. Żak, Przedsiębiorstwo ery nowej gospodarki, w: Zarzadzanie wartościa przedsiębiorstwa, red. E. Urbańczyk, „Studia i Prace Wydziału Nauk Ekonomicznych i Zarządzania Uniwersytetu Szczecińskiego" 2008, nr 6, s. 619.

3 K. Żak, op.cit., s. 620-621. 
5. Ujemnego sprzężenia zwrotnego i postępu - od przedsiębiorstw wymaga się „zdolności destrukcyjnych”, to znaczy umiejętności do rezygnacji z określonego produktu, zawodu, przemysłu, który aktualnie znajduje się na szczycie. W gospodarce sieciowej naturalnym zjawiskiem jest krótki cykl życia przedsiębiorstw, produktów, które podlegają ciągłym przegrupowaniom.

6. Nieefektywności - punkt ciężkości kładziony jest nie na ciągły wzrost efektywności działań, ale na poszukiwanie nowych szans rynkowych w otoczeniu.

W konsekwencji występowania omówionych reguł gospodarki sieciowej pojawia się konieczność wypracowywania nowego modelu przedsiębiorstwa, które różni się od tradycyjnie - pionowo - zorganizowanej firmy. Organizacje ery nowej gospodarki są określane mianem „organizacji relacji”, „organizacji związków”, „,sieci relacji międzyludzkich” czy ,przedsiębiorstw demokratycznych”4.

\section{Koncepcja organizacji fraktalnej}

Jedną z form zorganizowania nowego typu przedsiębiorstwa jest ta oparta na koncepcji fraktali. Fraktal (z łacińskiego fractus - złamany, cząstkowy) oznacza ,rodzaj figury geometrycznej, płaskiej lub przestrzennej, zazwyczaj charakteryzującej się własnością samopodobieństwa - małe fragmenty fraktala, oglądane w odpowiednim powiększeniu, wyglądają tak samo jak obiekt pierwotny"5. W potocznym rozumieniu fraktal oznacza samopodobny obiekt, którego części podobne są do całości. W 1975 r. B.B. Mandelbrot wprowadził fraktale do badań matematycznych. Geometria fraktalna dała $\mathrm{z}$ kolei możliwość matematycznego opisu i prognozowania rozwoju, m.in. zjawisk ekonomicznych, i znalazła zastosowanie w teorii zarządzania.

Definicja organizacji fraktalnej została stworzona przez H.J. Warneckego, który scharakteryzował ją, jako „samodzielnie działającą jednostkę przedsiębiorstwa, której cele i wydajność mogą być jednoznacznie opisane" Ws. Wspomniany autor w ramach tzw. fabryk fraktalnych wyodrębnił dwa poziomy: makrofraktale - całe or-

4 Ibidem, s. 624.

5 http://encyklopedia.pwn.pl/haslo/;3902416 (10.02.2015).

6 H.J. Warnecke, Rewolucja kultury przedsiębiorstwa. Przedsiębiorstwo fraktalne, Wydawnictwo Naukowe PWN, Warszawa 1999, s. 109. 
ganizacje i mikrofraktale - jednostki wchodzące w skład całej organizacji ${ }^{7}$. Z kolei R. Krupski fraktale definiuje jako elementy większej całości mające jednocześnie strukturę owej całości. Fraktale są miniaturkami przedsiębiorstwa, powiązanymi ze sobą efektywnym systemem komunikacji, dzięki czemu cele poszczególnych fraktali nie pozostają w sprzeczności z celami innych fraktali i celami przedsiębiorstwa jako całości. Cechą charakterystyczną przedsiębiorstwa fraktalnego jest decentralizacja i uelastycznienie struktur oraz uniwersalizacja, czyli odchodzenie od wysokiej specjalizacji każdego pracownika ${ }^{8}$. Przedsiębiorstwo fraktalne ma być zbudowane w oparciu o zespoły posiadające autonomię i prawo do organizowania się ${ }^{9}$. Natomiast M. Majewska definiuje fraktal jako „system sampodobnych jednostek o określonych właściwościach, (...) które mają wspólne cele i zasady działania, co sprawia, że są strukturalnie samopodobne i razem konstytuują spójną złożoną całość"10.

Reasumując, w koncepcji organizacji fraktalnej, fraktale (mikrofraktale) to elementy tworzące organizację. Ich struktura jest tożsama ze strukturą organizacji jako całości (makrofraktala). Czynnikami spajającymi poszczególne fraktale są: wydajny system komunikacji i cele fraktali. Cele te nie są im narzucane, ale ustalane w drodze wspólnego ich negocjowania oraz konkretyzowania, tak aby każdy z elementów organizacji fraktalnej mógł sformułować swój własny cel, wpisany w system celów całego przedsiębiorstwa. Fraktale charakteryzują się specyficznymi właściwościami (zobacz też tabela 1$)^{11}$ :

7 A. Binsztok, Koncepcja organizacji wirtualnej oraz organizacji fraktalnej jako odpowiedź na turbulencje otoczenia gospodarczego, w: Nowoczesne technologie informacyjne w zarzadzaniu, red. H. Dudycz, M. Dyszkowski, „Prace Naukowe AE im. O. Langego we Wrocławiu” 2004, nr 1044, s. 311 .

8 Zarzadzanie strategiczne. Badania, koncepcje, red. R. Krupski, Wydawnictwo Wałbrzyskiej Wyższej Szkoły Zarządzania i Przedsiębiorczości, Wałbrzych 2002, s. 12-13.

9 J. Martan, L. Lehkunów, Organizacja fraktalna - spoleczeństwo w skali mikro, czyli znana niewiadoma, w: Nowe tendencje w nauce organizacji i zarządzania, „Prace Naukowe Instytutu Organizacji i Zarządzania Politechniki Wrocławskiej. Studia i Materiały” 2006, nr 79, s. 83.

10 M. Majewska, Organizacja fraktalna jako strategia rozwoju wspótczesnego przedsiębiorstwa, Zeszyty Naukowe Uniwersytetu Szczecińskiego, „Problemy Zarządzania, Finansów i Marketingu" 2013, nr 747, s. 167.

11 K. Perechuda, Organizacja fraktalna, w: Zarządzanie przedsiębiorstwem przyszłości. Koncepcje, modele, metody. Formy i narzędzia skutecznego zarządzania przedsiębiorstwem, red. K. Perechuda, Placet, Warszawa 2000, s. 27-28; A. Binsztok, op.cit., s. 313; J. Martan, L. Lehkunów, op.cit., s. 84; K. Leja, Uniwersytet przyszłości organizacja fraktalna??, w: Koncepcje, modele, metody zarzadzania informacja $i$ wiedza, red. A. Binsztok, K. Perechuda, „Prace Naukowe Akademii Ekonomicznej we Wrocławiu" 2006, nr 1132, s. 150. 
1. Samopodobieństwo - to zdolność do powielania się. Duplikaty fraktali mają zbieżne cele, zadania i funkcje, co oznacza, że każdy problem orgaznizacyjno-zarządczy może być rozwiązany przez dowolną jednostkę organizacyjną.

2. Samoorganizacja - fraktale posiadają autonomię organizacyjną co do sposobów realizacji stawianych im celów. Nie jest wymagana aprobata menedżerów wyższego szczebla makrofraktala, nie są także potrzebne częste kontakty mikrofraktali z makrofraktalem, ponieważ makrofraktal wyznacza wizję, misję, politykę funkcjonowania, a mikrofraktale realizują cele w wybrany przez siebie sposób. Samoorganizacja to także zdolność do odrzucania nieprzyjaznych i niepasujących elementów. Zmianie ulega relacja podwładny-przełożony, ponieważ członkowie przedsiębiorstwa stają się jednocześnie własnymi zwierzchnikami.

3. Dynamika i witalność (zdolność życiowa, siła życiowa, żywotność) - fraktale mają zdolność samoklonowania się i adaptacyjnego reagowania na wpływy otoczenia. Działając, fraktale muszą wyprzedzać tempo zmian w otoczeniu, muszą to otoczenie samodzielnie kreować.

4. Samooptymalizacja - fraktale reorganizują się, powstają na nowo i ulegają rozkładowi, są elastyczne, działają na własną odpowiedzialność, mają zdolność do optymalnego wykorzystywania zasobów, oferując pełną dostępność znanych w organizacji środków i metod organizacyjno-zarządczych.

5. Samonawigowanie - fraktale permanentnie weryfikują poziom osiągania celów, co pozwala na sterowanie w kierunku wyznaczonym dla wszystkich jednostek fraktalnych. Dokonuje się analizy sprzężeń zwrotnych poszczególnych elementów działalności organizacji.

Tabela 1. Charakterystyka fraktali według różnych autorów

\begin{tabular}{|c|l|}
\hline \multicolumn{1}{|c|}{ Autor } & \multicolumn{1}{|c|}{ Cechy charakterystyczne fraktali } \\
\hline 1 & \multicolumn{1}{|c|}{2} \\
\hline H.J. Warnecke & $\begin{array}{l}\text { Samopodobieństwo, zdolność do samoorganizacji, samooptymalizacja, dyna- } \\
\text { mika, mierzenie i ocena swej wydajności, posiadanie niesprzecznego systemu } \\
\text { celów }\end{array}$ \\
\hline K. Perechuda & $\begin{array}{l}\text { Strukturalne podobieństwo, duża swoboda decyzyjna, możliwość funkcjonowa- } \\
\text { nia względnie niezależnie w długim okresie, samonawigowanie zorientowane } \\
\text { na tworzenie wartości dla klienta, wartość dodana generowana przez przedsię- } \\
\text { biorstwo stanowi synergię wartości dodanych tworzonych przez jednostki or- } \\
\text { ganizacyjne }\end{array}$ \\
\hline
\end{tabular}




\begin{tabular}{|l|l|}
\hline \multicolumn{1}{|c|}{1} & \multicolumn{1}{c|}{2} \\
\hline R. Krupski & $\begin{array}{l}\text { Elastyczność działania i możliwość szybkiego reagowania na zmiany w oto- } \\
\text { czeniu, system celów fraktali służy osiąganiu celów organizacji, samowystar- } \\
\text { czalność }\end{array}$ \\
\hline $\begin{array}{l}\text { H. Gienke, } \\
\text { R. Kämpf }\end{array}$ & $\begin{array}{l}\text { Samopodobieństwo, orientacja na cele, samoorganizacja, dynamika/witalność, } \\
\text { samooptymalizacja }\end{array}$ \\
\hline B. Mikuła & Samooptymalizacja i samoadaptacja do zmian w otoczeniu \\
\hline A. Binsztok & $\begin{array}{l}\text { Samoorganizacja, samopodobieństwo, samooptymalizacja, witalność, optyma- } \\
\text { lizacja wykorzystania zasobów organizacji, samonawigowanie, zdolność do } \\
\text { uczenia się, zdolność do działania w warunkach burzliwego otoczenia, wysokie } \\
\text { wymagania wobec członków organizacji w zakresie zdolności komunikowania } \\
\text { się, dzielenia się wiedzą, mobilności, elastyczności i odpowiedzialności w wy- } \\
\text { konywaniu procesów pracy }\end{array}$ \\
\hline
\end{tabular}

Źródło: opracowanie własne na podstawie: A. Binsztok, Koncepcja organizacji wirtualnej oraz organizacji fraktalnej jako odpowiedź na turbulencję otoczenia gospodarczego, w: Nowoczesne technologie informacyjne w zarzadzaniu, red. H. Dudycz, M. Dyszkowski, „Prace Naukowe AE im. O. Langego we Wrocławiu” 2004, nr 1044, s. 311-313.

Organizacja fraktalna cechuje się specyficznym typem struktury płaskiej, zbudowanej z dwóch poziomów: menedżera najwyższego szczebla i menedżerów poszczególnych fraktali, którzy są liderami zespołów roboczych (zobacz rysunek 1).

W ramach struktury funkcjonują niewielkie sztaby składające się z osób, które wspierają zarządzających w formułowaniu celów i nawigowaniu kierunku działania komórek. Na poziomie makrofraktala określane są cele strategiczne całego przedsiębiorstwa, a sam makrofraktal pełni funkcję koordynatora sieci. Na poziomie mikrofraktali ustalane są cele i sposoby działania poszczególnych jednostek, przy czym jednostki te mają szeroką autonomię stanowienia o sobie. Fraktale tworzą sieć powiązaną na zasadzie świadczenia wzajemnych usług, gdzie kluczowym czynnikiem sprawnego funkcjonowania jest efektywny system komunikacji. Sieć jest amorficzna - nie ma z góry określonego kształtu, ponieważ dowolny fraktal może wchodzić $\mathrm{w}$ alternatywne powiązania $\mathrm{z}$ innymi fraktalami $\mathrm{w}$ realizacji konkretnego procesu ${ }^{12}$. Ponadto, istnieje możliwość wyłączenia czasowego lub definitywnego pewnych fraktali lub włączania nowych. Warto jednocześnie zaznaczyć, że organizacja fraktalna ma widoczne granice. Choć jest otwarta na kooperacje z podmiotami otoczenia zewnętrznego, to zawsze w pierwszej kolejności wykorzystuje zasoby wewnętrz-

12 M. Hopej, Struktura organizacyjna fraktalnego przedsiębiorstwa, „Ekonomika i Organizacja Przedsiębiorstw” 2001, nr 3, s. 10-11. 
ne ${ }^{13}$. Zasadniczą formą organizacji procesów pracy jest praca zespołowa. Zespoły charakteryzują się niewielkim stopniem sformalizowania relacji, a ich członkowie rozumieją działania organizacji i aktywnie w nich uczestniczą.

Rysunek 1. Uproszczona struktura organizacji fraktalnej

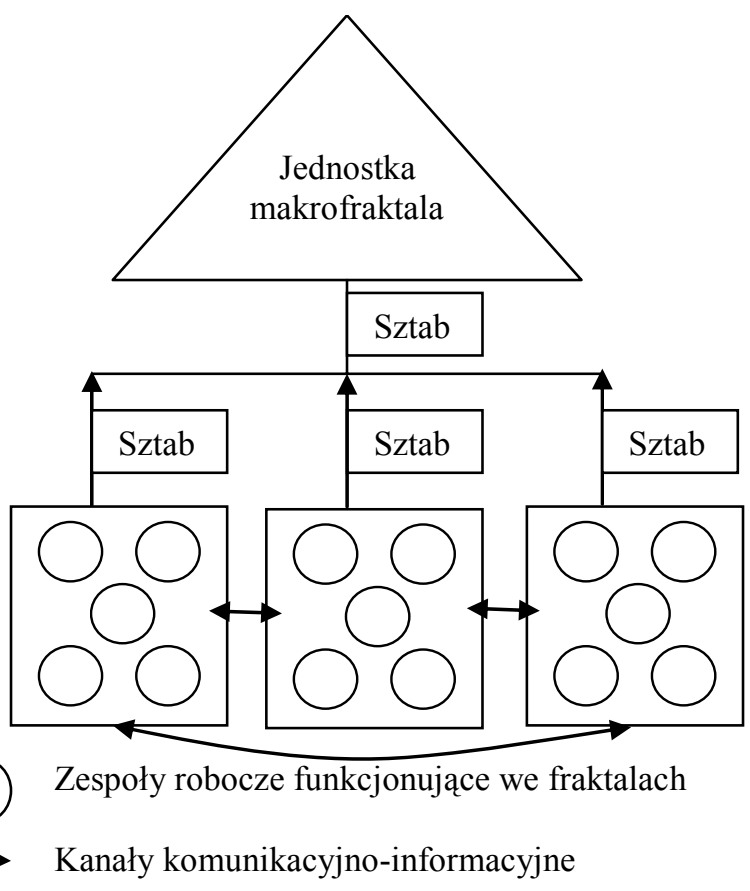

Źródło: M. Hopej, Struktura organizacyjna fraktalnego przedsiębiorstwa, „Ekonomika i Organizacja Przedsiębiorstw” 2001, nr 3, s. 11.

Tak zorganizowane przedsiębiorstwo ma zdaniem autorki szereg zalet. Po pierwsze, przejrzystość, ponieważ makrofraktalowi, będącemu centralą, podporządkowane są jednostki organizacyjne opierające swą pracę na autonomicznych zespołach roboczych - części służą całości i na odwrót. Występowanie tylko dwóch szczebli hierarchicznych daje dużą elastyczność całemu organizmowi w odpowiadaniu na zmiany wymogów rynku zewnętrznego i wychwytywanie okazji. Decentralizacja sprzyja także rozwiązywaniu problemów w miejscu ich powstawania, co

13 A. Binsztok, op.cit., s. 317. 
z kolei skutkuje szybkością reakcji. Ponadto, w przedsiębiorstwie budowany jest klimat współpracy i dzielenia się wiedzą, ponieważ każdy postrzegany jest jak klient wewnętrzny lub zewnętrzny, co umożliwia pozyskiwanie i rozwój wiedzy. Pracownicy, którzy rozumieją cele organizacji i mają dużą autonomię działania, wykazują większą tendencję do działań proaktywnych, odsiewają działania i projekty nieistotne, uruchamiając procesy, które tworzą wartość dodaną. Mają także świadomość, że drobne zakłócenia w realizacji procesów mogą spowodować katastrofalne skutki. Stąd też dąży się do eliminowania działań pospiesznych i chaotycznych, a czynności generowane są przy uwzględnianiu ich wpływu na procesy pracy współpracowników ${ }^{14}$.

Przedsiębiorstwo fraktalne nie jest jednak wolne od wad. Występowanie wielu fraktali o wysokim stopniu autonomii w wyborze celów i metod działania może doprowadzić do zjawiska dublowania się komórek i realizowanych procesów. Dlatego tak ważne jest ciągłe weryfikowanie poziomu realizacji celów w jednostkach (nawigowanie fraktalami). W tego typu przedsiębiorstwie stawia się bardzo wysokie wymagania wobec pracowników zarówno w obszarze umiejętności dzielenia się wiedzą, a więc zorientowania na kooperacją, a nie rywalizację, ale także w obszarze zdolności do funkcjonowania w warunkach wysokiej niepewności. Pracownicy mają wrażenie ciągłej tymczasowości, ponieważ przedsiębiorstwo, dostosowując się do zmian w otoczeniu, balansuje na krawędzi chaosu. Pojawia się problem z kreowaniem lojalności pracowników. Obszarami krytycznymi są kultura i tożsamość organizacyjna, ponieważ albo mogą zapobiegać dezintegracji i spajać ludzi wokół wspólnych wartości, albo, przy niewłaściwej dbałości, przyczynić się do rozpadu przedsiębiorstwa. Sprawne funkcjonowanie warunkowane jest także właściwym systemem komunikacji. Tylko istnienie wielu nieformalnych, zorganizowanych horyzontalnie kanałów informacyjno-komunikacyjnych zapewnia efektywną wymianę informacji i dzielenie się wiedzą.

\section{Podsumowanie}

Rozpoczynając artykuł od przedstawienia założeń funkcjonowania organizacji w warunkach gospodarki sieciowej, podkreślono konieczność zmiany podejścia do zarządzania $\mathrm{w}$ organizacjach przyszłości. Zdaniem autorki koncepcja

14 M. Hopej, op.cit., s. 10-11; K. Perechuda, op.cit., s. 31-32. 
organizacji fraktalnej zasługuje na szczególną uwagę, gdyż organizacja fraktalna wypełnia postulat organizacji przyszłości dzięki m.in. umiejętności szybkiego i elastycznego reagowania na zmiany $\mathrm{w}$ otoczeniu, demokratyzacji zarządzania czy samostanowieniu poszczególnych mikrofraktali. Niestety, choć organizacja fraktalna odpowiada wyzwaniom współczesnej gospodarki sieciowej, wciąż nie jest dostatecznie popularna $\mathrm{w}$ praktyce ${ }^{15}$. Zdaniem autorki taki stan rzeczy wynika głównie z faktu, że stworzenie przedsiębiorstwa fraktalnego wymaga nie tylko przeorganizowania tradycyjne zbudowanych firm w płaskie i elastyczne struktury, ale przede wszystkim - zmiany sposobu myślenia i filozofii zarządzania. Organizacja fraktalna bazuje na jemnym zaufaniu, partycypacji kompetentnych pracowników, dzieleniu się wiedzą, odejściu od konserwatywnej relacji przełożony-podwładny. Przełamywanie barier w przekonaniach zarządzających przedsiębiorstwami stanowi, według autorki, największe wyzwanie.

\section{Literatura}

Binsztok A., Koncepcja organizacji wirtualnej oraz organizacji fraktalnej jako odpowiedź na turbulencje otoczenia gospodarczego, w: Nowoczesne technologie informacyjne w zarzadzaniu, red. H. Dudycz, M. Dyszkowski, „Prace Naukowe AE im. O. Langego we Wrocławiu" 2004, nr 1044.

Hopej M., Struktura organizacyjna fraktalnego przedsiębiorstwa, „Ekonomika i Organizacja Przedsiębiorstw" 2001, nr 3.

http://encyklopedia.pwn.pl/haslo/;3902416 (10.02.2015).

Leja K., Uniwersytet przyszłości organizacja fraktalną?, w: Koncepcje, modele, metody zarzadzania informacja $i$ wiedza, red. A. Binsztok, K. Perechuda, „Prace Naukowe Akademii Ekonomicznej we Wrocławiu" 2006, nr 1132.

Majewska M., Organizacja fraktalnajako strategia rozwoju wspótczesnego przedsiębiorstwa, Zeszyty Naukowe Uniwersytetu Szczecińskiego, „Problemy Zarządzania, Finansów i Marketingu" 2013, nr 747.

15 K. Leja sformułował propozycję zastosowania koncepcji fraktali w nowoczesnej uczelni. Zwraca uwagę, że dziś uczelnie wyższe działają w trudnych warunkach, ponieważ rynek usług edukacyjnych i badawczych jest coraz bardziej konkurencyjny przy zmiennej sytuacji demograficznej i rosnącej popularności kształcenia na odległość. Stąd potrzeba stworzenia tzw. przedsiębiorczego uniwersytetu. Nowy sposób zorganizowania uczelni opierałby się na funkcjonowaniu dwóch poziomów - makrofraktali, czyli władz uczelni, i mikrofraktali badawczych i dydaktycznych niezależne od siebie, ale otwartych na współpracę. Szerzej na ten temat: K. Leja, op.cit. 
Martan J., Lehkunów L., Organizacja fraktalna - społeczeństwo w skali mikro, czyli znana niewiadoma, w: Nowe tendencje w nauce organizacji i zarzadzania, „Prace Naukowe Instytutu Organizacji i Zarządzania Politechniki Wrocławskiej. Studia i Materiały” 2006, nr 79.

Perechuda K., Organizacja fraktalna, w: Zarządzanie przedsiębiorstwem przyszłości. Koncepcje, modele, metody. Formy i narzędzia skutecznego zarządzania przedsiębiorstwem, red. K. Perechuda, Placet, Warszawa 2000.

Warnecke H.J., Rewolucja kultury przedsiębiorstwa. Przedsiębiorstwo fraktalne, Wydawnictwo Naukowe PWN, Warszawa 1999.

Zarządzanie strategiczne. Badania, koncepcje, red. R. Krupski, Wydawnictwo Wałbrzyskiej Wyższej Szkoły Zarządzania i Przedsiębiorczości, Wałbrzych 2002.

Żak K., Przedsiębiorstwo ery nowej gospodarki, w: Zarządzanie wartościa przedsiębiorstwa, red. E. Urbańczyk, „Studia i Prace Wydziału Nauk Ekonomicznych i Zarządzania Uniwersytetu Szczecińskiego" 2008, nr 6.

\title{
THE FRACTAL ORGANIZATION IN THE NEW ECONOMY
}

\begin{abstract}
In the article the author presents the idea of fractal organization as the one that faces demands of The New Economy. Different definitions of fractal, its characteristics and potential advantages and disadvantages are shown.
\end{abstract}

Translated by Anna Wieczorek-Szymańska

Keywords: The New Economy, fractal organization, management

JEL Code: L22 